\title{
COMPLETE OSSIFICATION OF STYLOHYOID LIGAMENT
}

\author{
Bilodi A.K.S.
}

Mishra D. ${ }^{2}$

Sinha B.N. ${ }^{3}$

\begin{abstract}
:
In this particular case the whole of the stylohyoid ligament has been ossified so that styloid process and stylohyoid ligament are continuous piece of the bone. It is a very rare anomaly seen in a lady aged 36 years at ENT OPD of Nepalgunj Medical College Teaching Hospital, Nepalgunj, Nepal. No book or journal has described a bilateral complete ossification of stylohyoid ligament in man. Hence it has been reported.
\end{abstract}

Key Words: Lesser cornua, epihyal bone, styloid process, stylohyoid ligament. hyoid bone. (Reicherts Cartilage)

\section{INTRODUCTION:}

Stylohyoid ligament extends from the tip of styloid process of temporal bone to the lesser cornua of the hyoid bone. The skeletal element of the second brachial arch (Reicherts cartilage) forms stapes, styloid process, stylohyoid ligament, and lesser cornua of hyoid bone. Stapes, styloid process and lesser cornua of the hyoid bone get ossified but stylohyoid ligament remains fibrous. Sometimes ossification extends into the stylohyoid ligament so that the lengths of the styloid process and stylohyoid ligaments are inversely proportional.

\section{DEVELOPMENT:}

Reichert's cartilage is formed from the neural crest cells derived from the cranial end of Myelencephalon (Caudal subdivision of Rhombencephalon)

\section{CASE REPORTS:}

A lady aged 36 years came to OPD of ENT department of Nepalgunj Medical College Teaching Hospital at Nepalgunj, Nepal with history of Sticky sensation in the throat and abnormal sensation in both ears during swallowing for the last six months.

1. MBBS, MS. (Anatomy), Asst. Pro. of Anatomy, Dept. of Anatomy, Nepalgunj Medical College, Chisapani, Banke.

2. MBBS, MS. (ENT), Lecturer in ENT, Nepalgunj Medical College, Teaching Hospital, Nepalgunj, Nepal.

3. MBBS, MS. (Anatomy), Pro. of Anatomy, Dept. of Anatomy, Nepalgunj Medical College, Chisapani, Banke, Nepal. Address for correspondence : $\quad$ Dr. Arun Kumar S. Bilodi, MBBS, MS. (Anatomy)

Assistant Professor of Anatomy, Department of Anatomy, Nepalgunj Medical College, Chisapani, Banke, Nepal. 
She had similar complaints in the past but there was no family history of such complaints.

Fig. 1

\section{ON EXAMINATION:}

She was anemic with poor oral hygiene.

1. Oral cavity examination revealed the following:

a) Post pharyngeal wall was granular and congested.

b) Both tonsils were not enlarged.

c) Indirect laryngoscopy - normal

2. Examinations of ears - Bilateral tuning fork test was normal

3. Higher centers - were normal

4. On X-Ray stylohyoid legament was found completely ossified on both sides extending from styloid process to lesser horn (Cornua) of hyoid bone.

\section{DISCUSSION:}

Stylohyoid ligament is formed by conversion of succeeding part of the dorsal segment of Reichert's Cartilage and its sheath. Endochondral ossification takes place in the ligament to form cranial part of hyoid bone and lesser horn of hyoid bone. ${ }^{1}$

Reichert's Cartilages is a cartilaginous bar of second arch. Dorsally it extends up to cartilaginous ear capsule. It has a dorsal and ventral part. Stapes of the middle ear is formed by ossification of dorsal part of the cartilage, following which stylohyoid ligament and styloid process of temporal bone are formed by succeeding part. Lesser cornua of the hyoid bone and the upper rim of the hyoid bone is also formed from the second arch which is also known as Hyoid Arch. Later the cells of the cartilage disappear. ${ }^{2}$

Muscles of facial expression, stapes, facial nerve also develop from the second arch cartilage.

Stylohyoid ligament extend from tip of styloid process and lesser horn of hyoid bone. Remanants of second pharyngeal arch cartilage are styloid process and stylohyoid ligament. There will be disappearance of unossified cartilage but perichondrium persists as stylohyoid ligament. It may remain as distinct bone called EPIHYAL bone in many mammals. Length of styloid process and stylohyoid ligament are inversely propotional. $5,6,7,8$

\section{PRESENT STUDY:}

In the present study, a female patient age 36 years came to ENT OPD of Nepalgunj Medical College Teaching Hospital at Nepalgunj, Nepal with a history of sticky sensation in the throat and abnormal 
sensation in both ears during swallowing of 6 months duration. She was examined clinically and investigated. All her parameters were normal but radiological examinations revealed complete ossification of stylohyoid ligament on both sides, so that stylohyoid process and stylohyoid ligament were one continuous piece of bone. This is a very rare anomaly. There was no distinct bone called EPIHYAL bone and no other abnormality was noted. She was offered symptomatic treatment and counselling.

\section{CONCLUSION:}

Sometimes ossifications extend into the stylohyoid ligament so that length of the styloid process and stylohyoid ligament are inversely proportional. Search of the published elsewhere could not reveal. Hence, this case has been presented complete bilateral ossified stylohyoid ligament. This abnormal ossification may have caused sticky sensation in the throat and abnormal sensation in both ears during swallowing.

\section{ACKNOWLEDGEMENTS:}

My sincere thanks to Managing Director, Director of Lord Buddha Educational Academy, Principal, Prof. and HOD of anatomy department, and anatomy department staff Mr. K.P. Singh librarian - Nepalgunj Medical College, Chisapani.

\section{BIBLIOGRAPHY:}

1. Arey Leslie Breinerd - Developmental Anatomy - A text book and laboratory manual of embryology W.B. Saunders Company $7^{\text {th }}$ edition 419 p. (1966)
2. Dutta $\mathrm{AK}$ - essentials of Human Embryology - Current Books International - $2^{\text {nd }}$ edition, 115 p. (1991)

3. Decker GAGet al Lee Mc Gregor's synopsis of surgical anatomy - K M verghese and company Bombay - Indian Edition $12^{\text {th }}$ edition 176 p. (1986)

4. Larsen William J. - Human Embryology Churchill Living stone $2^{\text {dd }}$ edition 358 p. (1997)

5. Mc. Minn. RMH Last's Anatomy - Regional and applied Churchill Ligingstone Singapore International student edition $9^{\text {th }}$ edition 165 p. (1994)

6. Sahana SN. - Human Anatomy Descriptive and Applied vol. 1 K.K. Publishers Private Limited, Howrah 480 p. (1993)

7. Singh Inderbir - Human embryology Mc. Millan India Ltd.,Madras - $5^{\text {th }}$ edition - 124 p. (1993)

8. Williams - Grays anatomy ELBS with Churchill Living stone London $37^{\text {th }}$ edition 584 p. (1992) 